\title{
Social Inequalities and Vulnerability of population facing the COVID-19: the case of Seine-Saint-Denis in Ile-de-France.
}

\author{
Stéphane GOUTTE* \\ Université Paris-Saclay, UVSQ, CEMOTEV, 78280, Guyancourt, France \\ Thomas PÉRAN \\ Executive Director at ROLACC Geneva, 211 oute de Ferney, CH1218,Le Grand-Saconnex
}

Research Fellow at Université de Paris.

Thomas PORCHER

PSB, Paris School of Business, 59 rue Nationale, 75013, Paris, France.

May 19, 2020

\begin{abstract}
The vast majority of research focuses on the individual factors leading to coronavirus mortality. Numerous studies have shown that the age of the population is the dominant factor explaining mortality. Other more recent work has added gender, comorbidity, ethnicity and obesity. Based on the most populous and dense region of France - Île-de-France, grouping 8 heterogeneous departments in terms of wealth — our study seeks to identify whether economic and financial or structural factors related to housing can explain a faster circulation of the virus during social distancing like lockdown, and therefore lead to excess mortality. We show that agglomerations with higher precariousness indicators (unemployment benefit income, poverty rate, social minima in income, little or no graduate in the workforce) and less suitable housing (potentially unworthy housing, household size, overcrowded housing) are more at risk, including if their population is younger. Our study therefore provides political leaders with a number of indications allowing them to take effective measures in the event of a second wave of COVID-19 or forthcoming coronavirus pandemics.
\end{abstract}

Keywords: Pandemic; COVID-19; Social distancing; Health system; Territorial vulnerabilities; Poverty; Housing JEL classification:I14; I18; J14; H12; R11

\footnotetext{
*Corresponding author: johngoo@uakron.edu
} 


\section{Introduction}

On the 11th of March 2020, the Director General of the World Health Organization (WHO) declared the COVID-19 epidemic as an ongoing pandemic, while more than 110 states were heavily affected worldwide, totalizing approximately 120,000 cases of coronavirus (WHO, 2020a). Very quickly, researchers from around the World devoted their work to the study of this new virus, by mainly using three different approaches. First, a race against the clock was launched by epidemiologists to find a vaccine (Shoenfeld, 2020; Cohen, 2020; Thanh, Andreadakis et al., 2020) and reach in the earliest possible delay a satisfactory level of collective immunity (Altmann, Douek and Boyton, 2020). Second, the medical profession devoted itself to studying the effects of the virus on the health of individuals. Finally, the major part of researchers has tried to identify the most effective ways to staunch this global scourge. Relative to this last axis in which this current study fully fits, we aim to understand what are the factors of transmission of the virus (Li, Xu et al., 2020) and worsening of the situation health (Di Lorenzo and Di Trolio, 2020), but also to assess the extent of the economic consequences that the health crisis inevitably causes (McKee and Stuckler, 2020; Yue, Shao et al., 2020).

Fundamental elements to understand the COVID-19 phenomenon are immediately revealed by the first studies. It is thus demonstrated that the source of the pandemic is to be located in the Chinese city of Wuhan inside Hubei Province and that in the category of elderly individuals (NHS England, 2020) the highest mortality rate is to be deplored. Extremely fast, these results are refined to allow a precise identification of other comorbidity factors (Bacon, Bates et al., 2020). Thus, for example, it seems very likely that patients suffering from other pathologies such as diabetes (Klonoff and Umpierrez, 2020) or asthma (Abrams and Szefler, 2020; WHO, 2020b) are more affected than healthiest patients, but also that the rhesus of the blood group and the ethnic origin of the patients (Mihm, 2020; NHS England, 2020; Webb Hooper, Nápoles and Pérez-Stable, 2020) could constitute a medical field fostering the mortality of the virus. In other words, a standard "robot portrait" of the patient most at risk in front of COVID-19 is already drafted.

On the other hand, geographical studies show that if not a single continent is sheltered ${ }^{1}$ (Hopman, Allegranzi and Mehtar, 2020; Gilbert, Pullano et al., 2020), we observe within the West the highest morbidity rate, according to the following top Global ranking: United States of America (i 79,500 deaths), United Kingdom (i. 31,900 deaths), Italy (i. 30,500 deaths), Spain (i. 26 600), France $(i, 26,300)^{2}$. Therefore, in order to better understand the vectors of the virus transmission as well as the morbidity factors, it seems interesting to conduct comparative studies at the three continental, regional and State levels.

\footnotetext{
${ }^{1}$ It also seems that not a single country has been sheltered and that the few localities where no deaths have been recorded have chosen not to report the cases. Refer to figures from Johns Hopkins University which are widely accepted by the Global scientific Community. Available at: https://coronavirus.jhu.edu/map.html (accessed 10 May 2020).

${ }^{2}$ Figures updated to May 11, 2020.
} 


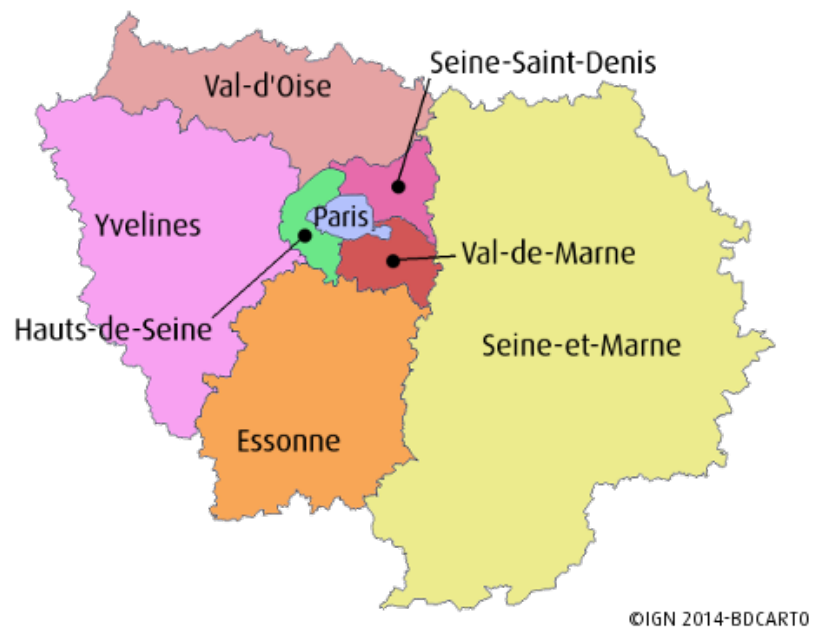

Figure 1: Map of Île-de-France

However, the first observations establish that biases exist and that it therefore could be reasonable to limit comparative analyzes to territorial units with the same human and climatic characteristics (Desjardins, Hohl and Delmelle, 2020; Liu, Zhou et al., 2020). For example, the observation is made that in Sub-Saharan Africa, the contamination and transmission/propagation rates are extremely low compared to the countries in the North and West of the Globe (Martinez-Alvarez, Jarde et al., 2020; Nuwagira and Muzoora, 2020). The positive effects of various factors are discussed in this regard, such as the protective role of previous injections of Malaria vaccine on populations exposed to COVID19 (Sargin and Yavasoglu, 2020). Moreover, the global death Report show that the counting of national deaths is not uniform. Some countries report exclusively deaths in hospital (like France at the early stage of the pandemic) while others merge deaths in hospital, domestic and nursing homes (like Germany). Accordingly, an international study seems to be unrealistic at the moment.

Compared to the other research papers mentioned above, our study proposes an approach to the structural factors of contamination/contagion/mortality, rather than a focus on human factors. In other words, it is a question of asking whether, in addition to genetics and geography, new elements can be put forward to explain the excess mortality in certain populations. For this, we have limited our research to Île-de-France (see Figure (2.1)), a French region built of eight departments ${ }^{3}$, which has the unique characteristic of not constituting a cluster of contamination due to an identifiable and outstanding event.

\footnotetext{
${ }^{3}$ In France, administrative levels in order of importance (ascending order) are municipalities/agglomerations (35 357 units), departments (101 units) and regions (18 units).
} 
Indeed, certain territorial units have formed clusters of contamination largely responsible for the degree of contamination at the National level. For example, in the French city of Mulhouse belonging to the Grand Est region, a major gathering of faithful evangelists is considered to be responsible for a nonnegligible part of the whole excess mortality linked to COVID-19 among the State. In addition, the Île-de-France region is highly populated with 12174 880 million inhabitants (19\% of the whole French population) and socially heterogeneous (ethnicity, professional qualification of workers, graduate of higher education, quality of the health system...) but its boarders stand inside a small geographic area with no climatic ecosystems effects. Under these conditions, Îlede-France constitutes a relevant field of study for the various structural factors other than individual ones like age or comorbidities promoting the contamination/contagion/mortality tryptic.

\section{Data and Approach}

Starting with a large panel of 66 variables ${ }^{4}$ which were representative of the economic, financial or structural factors related to housing in Ile de France and its population. This data collects, analyses and disseminates information on the French economy and society. We finally select using a Principal Component Analysis (PCA) a closer panel of 30 variables which are all more significant in term of segmentation of our Departments (and in particular the Seine-SaintDenis).

\subsection{Principal Components Analysis}

Thus in order to characterize the best set of discriminant variables we proceed with a principal component analysis. This approach allows us to best capture the explanatory and segmenting power of the variables we have.

\footnotetext{
${ }^{4}$ taken from the statistical database of The National Institute of Statistics and Economic Studies (INSEE)
} 
Figure 2: Projection of IDF Departments on the two main PCA axis

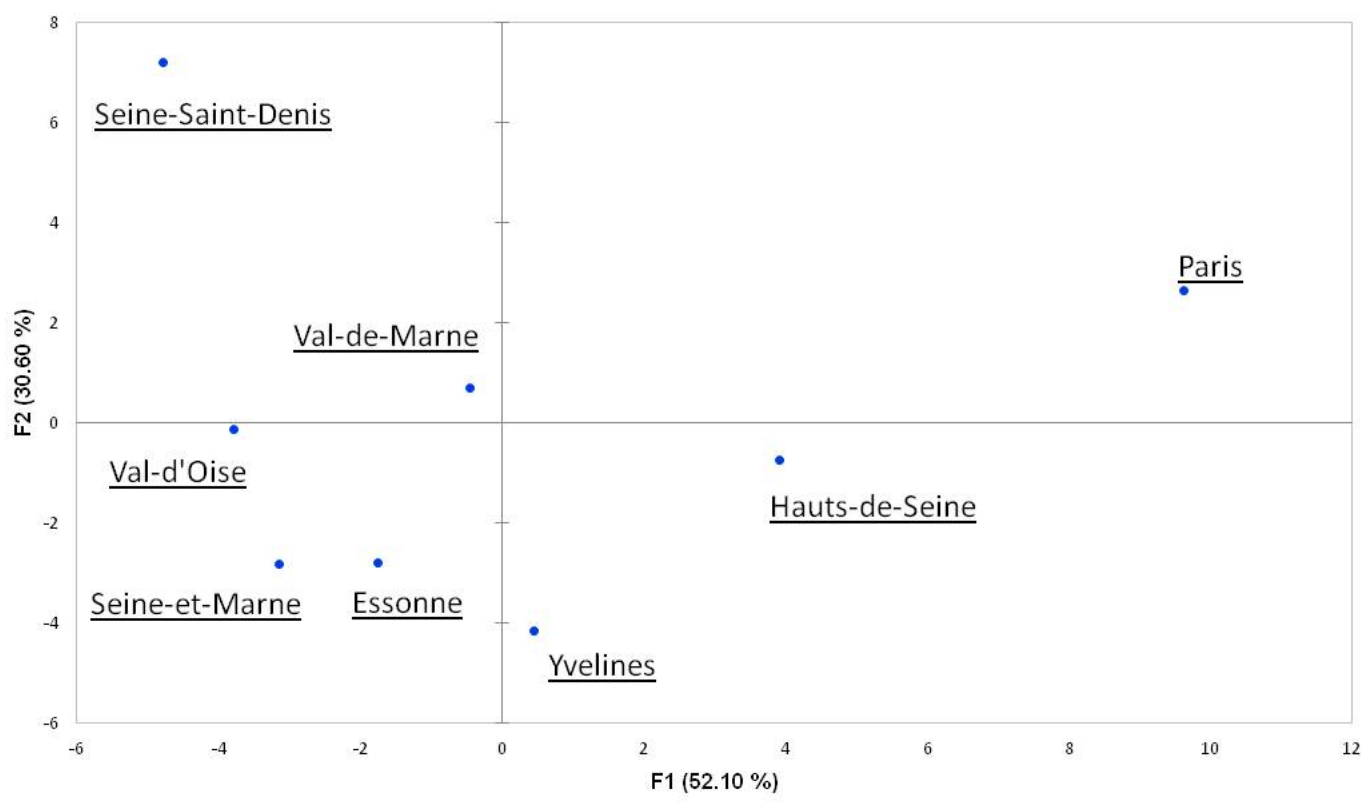

The Figure 2.1 shows the best representation (projection) in two dimensions of our 8 departments regading the set of available variables. We see clearly that the department of Seine-Saint-Denis is far away from the others (in the upper left position) which argues in favor of a significant difference in term of variable values from the others departments in Ile de France. Thus, this prove that a study of the specificities of this departments is useful and relevant to understand and explain the reasons and factors which brought to this excess of mortality in Seine-Saint-Denis. Moreover, we can see that the most distant and therefore different departments with repsect to Seine-Saint-Denis are Paris and Haut de Seine. The can see in Figure 2.1, the cumulative variability obtained by taking a representation in this only two main factor axis equals $82.70 \%$. This prove the statitical relevance of this projection. 
Figure 3: Cumulative Variability obtained for each factor axis

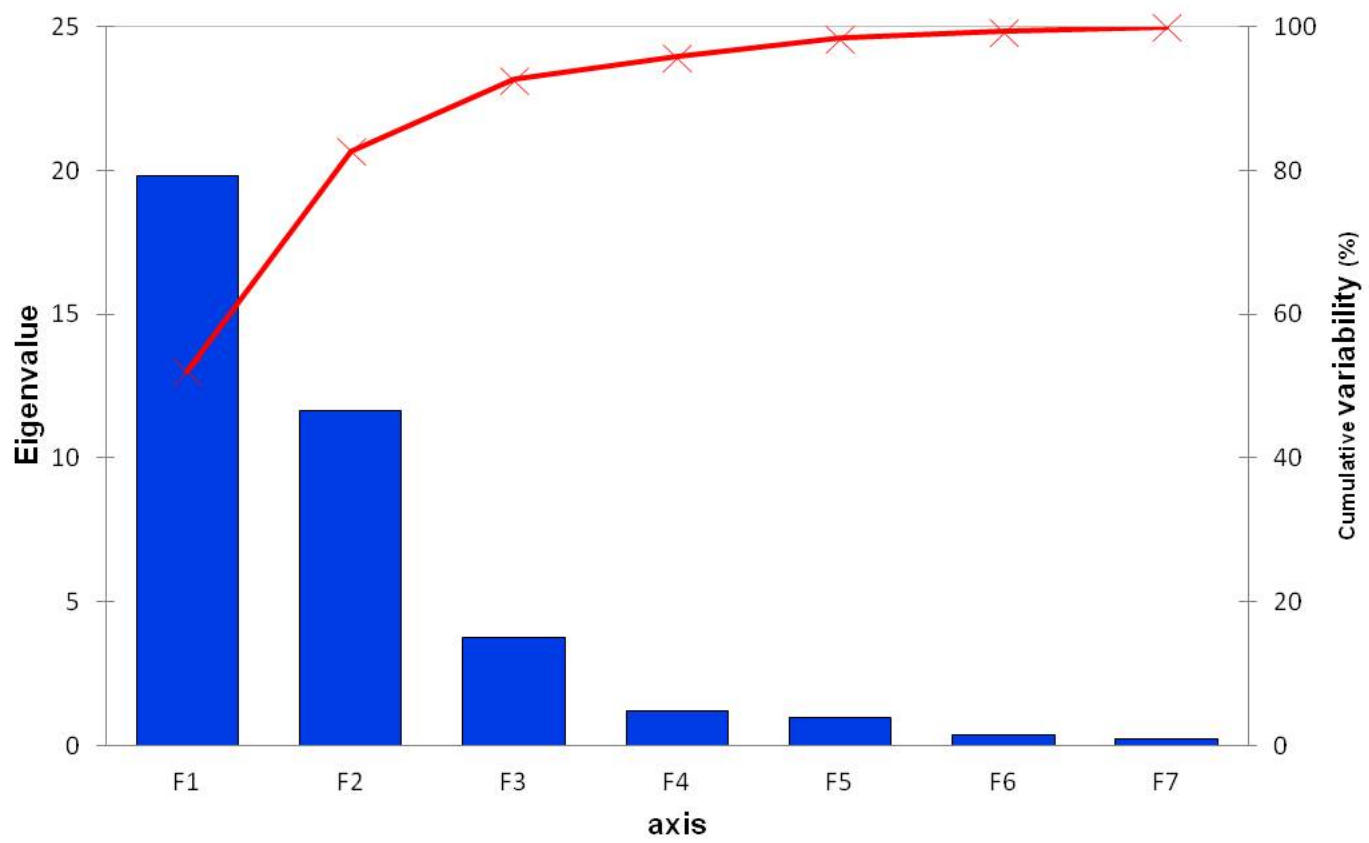

If we want to go more deeply in the explanation of this segmentation, we can take a look on the weights of each variables given by each two axis. These results are provided in Table 1 . We can see that a positive value on the first axis (i.e. horizontal) characterizes:

- a high share of graduates of higher education in pop. out of school 15 years or more at a level of $96.50 \%$

- Average household size at a level of $95.96 \%$

- a high value of the aging index at a level of $93.60 \%$

- a high average hourly net salary at a level of $85.45 \%$

This means that a department with a high coordinate in this Factor 1 exhibits all this points; and higher is its coordinate higher is these factors. The projection of IDF Departments on the these two main PCA axis are stated in Table 2.

The Departments of Paris and Haut de Seine which take a high value in this axis projection are so fundamentally and intrinsically characterized and determined by a population with a high level of education, with a higher salary 
than the other departments and an older population than the other one. This last factor is of course the main reason why the mortality are important in both departments.

Conversely, the Seine-Saint-Denis department which takes the most negative value in this projection is so characterized by a younger population with a less level of education and so an average value of salary at the end. But, as we show previously, its excess of surmortality dues to COVID-19 is the higher. We so have to look the interpretation of the second axis (i.e. vertical) since the SeineSaint-Denis is again isolated than the other departments in the upper region (i.e. positive values).

We can see that a positive value in this factor characterizes:

- a high number of main residences overcrowded at a level of $96.00 \%$.

- a high share of private park accommodation potentially unworthy (PPPI) at a level of $91.44 \%$

- a high number of people living in an apartment in a household of at least 4 people at a level of $88.83 \%$

- a high poverty rate at a level of $88.20 \%$

- a high value of share of unemployment benefits in the rev. avail. at a level of $72.74 \%$

This means that the Seine-Saint-Denis is highlighted by very difficult economic and health conditions: overcrowded housing, potentially unworthy; a low-income population, mostly from income linked to unemployment benefits. Hence, conditions socio-economics which bring surmortallity in period of pandemic. 
Table 1: Explication Weights of each variables on the two main axis factor

Unemployement rate

F1 F2

People 65y and more

$0,381558 \quad 0,5903711$

People $75 y$ and more

$0,700227 \quad 0,2170222$

Aging index

$0,684784 \quad 0,1869943$

Population density

$0,936031 \quad 0,002343$

Average household size

$0,697611 \quad 0,2897714$

Median standard of living

$0,959639 \quad 0,0040854$

Share of taxed tax households

$0,659438 \quad 0,3188606$

Share of unemployment benefits in the rev. avail.

$0,49332 \quad 0,488439$

Part des prestations logement dans le rev. disp. 2016

$0,24914 \quad 0,7274552$

Share of social minima in rev. avail.

Taux de pauvreté 2016

$0,343963 \quad 0,6314759$

$0,315023 \quad 0,6619699$

Share of pops with little or no diploma.

out of school 15 years or more

$0,107143 \quad 0,8820404$

Share of graduates of higher education

in pop. out of school 15 years or more

$0,721121 \quad 0,2702388$

Share of apartments in total housing

Share of houses in total housing

Share of owners of their residences

Share of HLM tenants in main residences

Share of workers in the number of jobs

Activity rate by age group

Public Service Workforce

Average hourly net salary

Share of admin positions. public, education, health and social action in institutions. assets

General practitioner

Nurses

Pharmacy

Elderly accommodation

Nursery

Pôle emploi

Infant School

Elementary school

$0,965011 \quad 0,0075429$

$0,556234 \quad 0,3294512$

$0,559437 \quad 0,3305705$

$0,351085 \quad 0,6040112$

$0,116735 \quad 0,518652$

$0,741465 \quad 0,0183661$

$0,651726 \quad 0,2236003$

$0,670789 \quad 0,1730079$

$0,85455 \quad 0,0579598$

Middle school

$0,409242 \quad 1,106 \mathrm{E}-05$

$0,780782 \quad 0,0758108$

$0,564617 \quad 0,0727833$

$0,798154 \quad 0,1077442$

$0,807258 \quad 0,0102245$

$0,911818 \quad 0,0793671$

$0,094789 \quad 0,0435737$

$0,191453 \quad 0,0657052$

$0,058083 \quad 0,1342393$

$0,344103 \quad 0,2657882$

$0,662656 \quad 0,1517911$

$0,683236 \quad 0,0466165$

Emergency service

$0,017171 \quad 0,9595219$

Number of main residences overcrowded Part (\%)

$0,570496 \quad 0,3373785$

People living in an apartment in a household of at least 4 people

Share of private park accommodation potentially

unworthy (PPPI) - Source Dhrill

$0,141567 \quad 0,828304$

$0,045632 \quad 0,9143809$ 
Table 2: Projection of IDF Departments on the two main PCA axis

$\begin{array}{lrr} & \text { F1 } & \text { F2 } \\ \text { Paris } & 9,605195 & 2,654331 \\ \text { Seine-et-Marne } & -3,14978 & -2,797914 \\ \text { Yvelines } & 0,442294 & -4,153429 \\ \text { Essonne } & -1,7583 & -2,790276 \\ \text { Hauts-de-Seine } & 3,911152 & -0,734134 \\ \text { Seine-Saint-Denis } & -4,79127 & 7,2151162 \\ \text { Val-de-Marne } & -0,45865 & 0,7085487 \\ \text { Val-d'Oise } & -3,80063 & -0,102243\end{array}$

\section{Results}

The list of these variables can be see in Tables 3 to 7 in Appendix. To compare the values of these set of variables we decided to evaluate the variation in percentage of each value for each department with respect to the average of the region. It means that a value of $10 \%$ represents that this department has a value $10 \%$ higher than we average of all departments in Ile de France. 


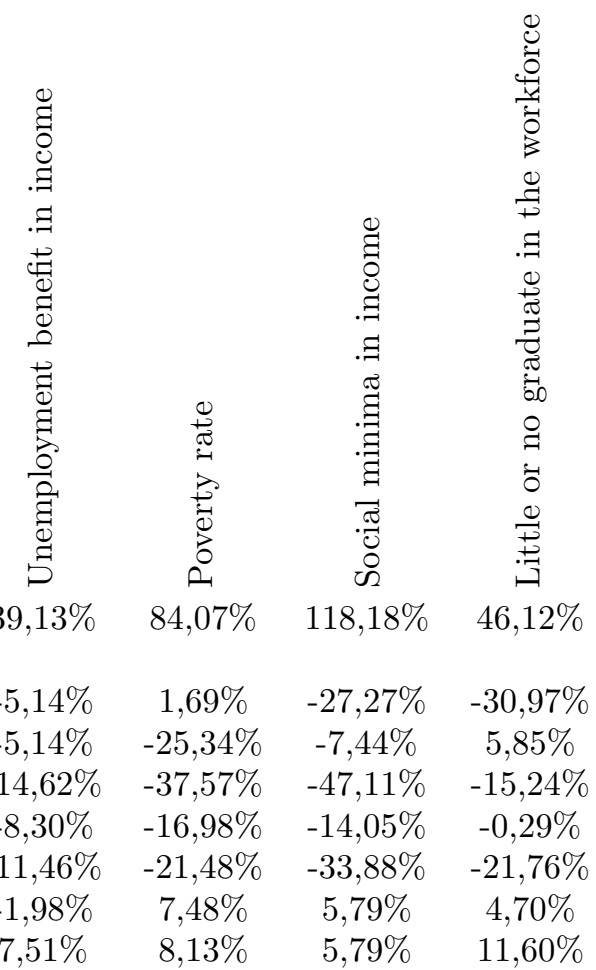

Our study provides interesting results. We note in Figure 3 that the link between the population over age of 75 and excess mortality is not absolute. 
Seine-Saint-Denis $\quad 104,78 \%$

$9,47 \% \quad 68,16 \%$

Paris $\quad 77,47 \% \quad-20,00 \% \quad 29,80 \%$

Seine-et-Marne $\quad-37,20 \% \quad 5,26 \% \quad-38,78 \%$

Yvelines

$-64,51 \% \quad 1,05 \% \quad-40,41 \%$

Essonne

$-72,70 \% \quad 5,26 \% \quad-28,98 \%$

Hauts-de-Seine

$-4,44 \%$

$-7,37 \% \quad 6,12 \%$

Val-de-Marne

$-1,71 \%$

$-3,16 \% \quad 11,84 \%$

Val-d'Oise

$-1,71 \%$

$9,47 \%$

$-7,76 \%$

Figure 4: Link between Age and Excess mortality

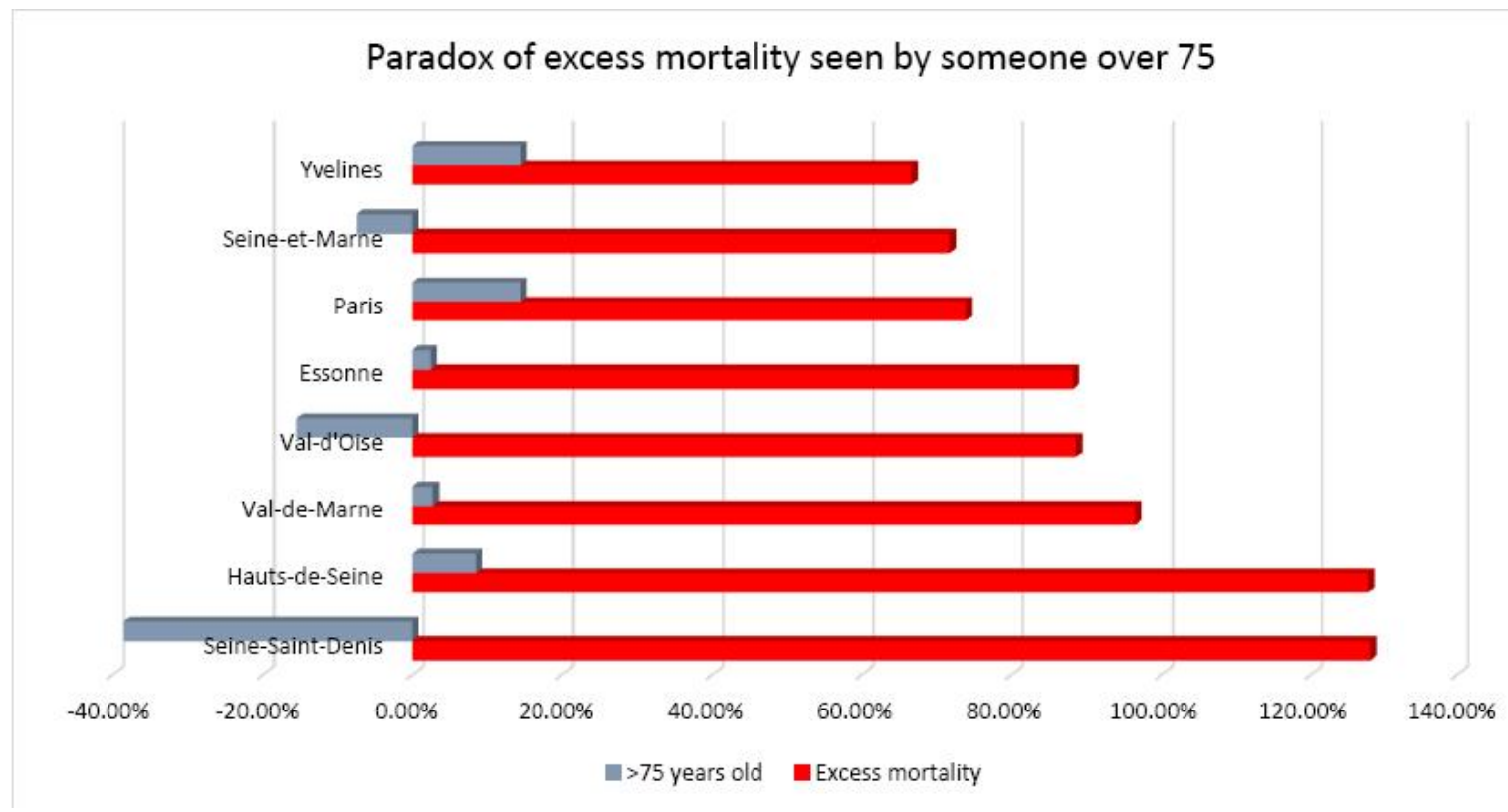


Figure 5: Economic Inequalities

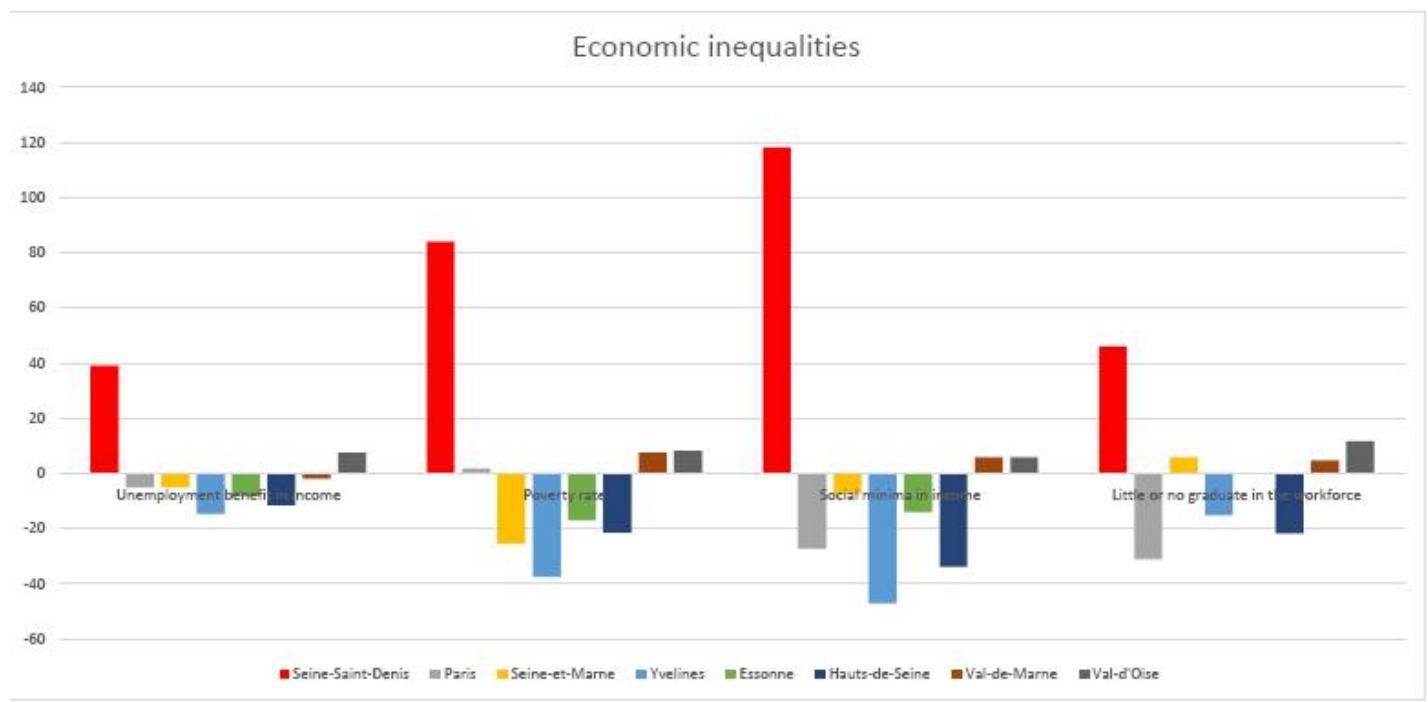

Two departments with the highest population deltas over age of 75 , Paris $(+14.38 \%)$ and Yvelines $(+14.38 \%)$, are among the departments with the lowest excess mortality (respectively $+73,90 \%$ and $+66.60 \%$ ). Conversely, while SeineSaint-Denis department displays the lowest delta on the population over 75 $(-38.51 \%)$ it shows the highest excess mortality $(+128.10 \%)$. Theoretically, the standard observation would have been the opposite side: The high mortality rate observed among people over $75 \mathrm{~s}$ in France, representing $78.3 \%$ of deaths with an average age of 81.2 (Santé Publique France, 2020), should have led to a negative ranking on such departments. The Val-d'Oise is also a department with a negative delta regarding the population over 75 years old $(-15.54 \%)$ but with the fourth excess mortality in Île-de-France $(+88.6 \%)$. Seine-et-Marne department has also a smaller population of over $75(-7.41 \%)$ associated to an excess mortality rate of $+71.70 \%$. 
Figure 6: Inequalities linked to housing

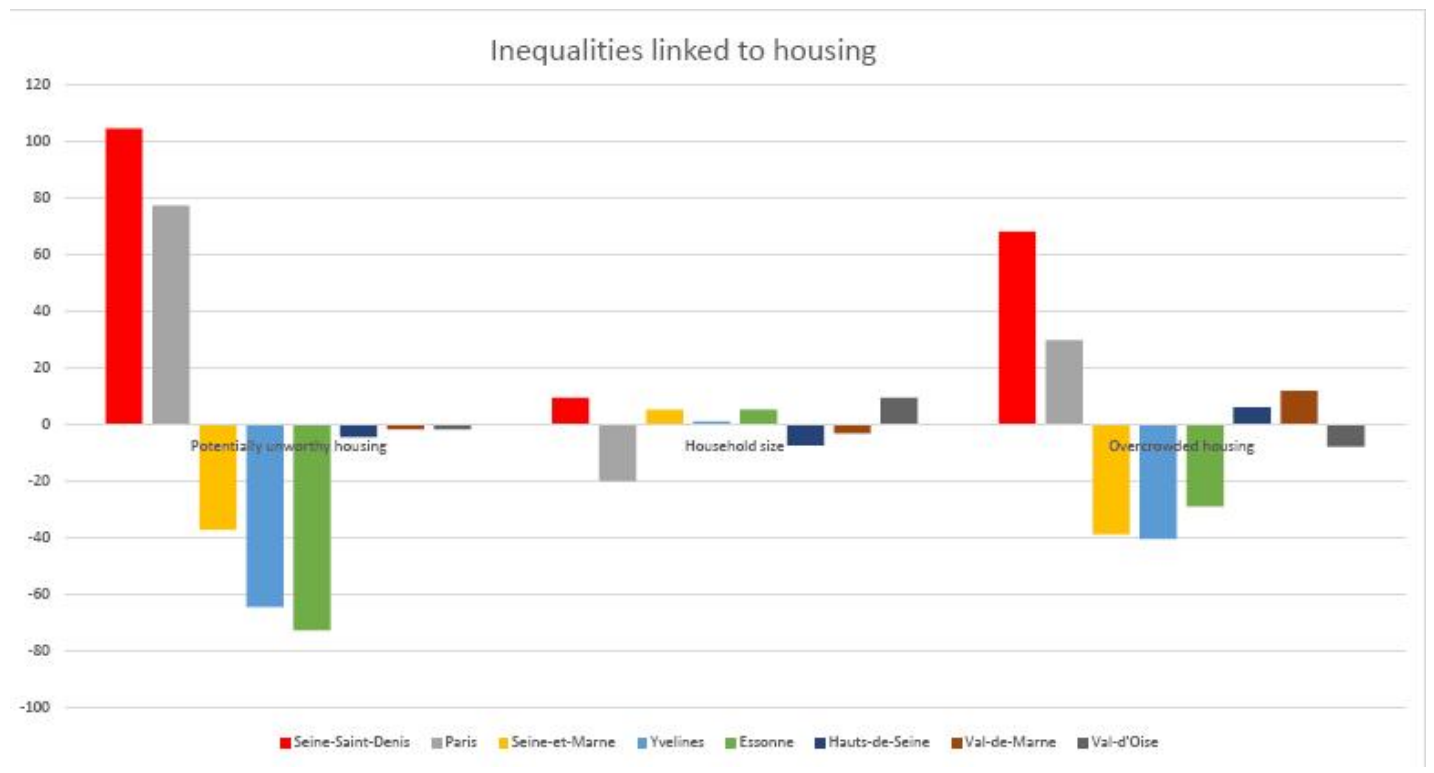

Our study allows us to identify a broader number of factors, first, and to point out the specificity of each department with a significant excess mortality despite their more advantageous demography compared to others, second. By taking economic, social and financial variables that can reveal the insecurity of department populations, such as unemployment benefits, poverty rate, minimum social benefits or level of education, and by adding variables specific to the structure of housing, we offer a chance to implement tailor-made structural policies. For instance, in regard to unemployment benefit income, we observe that Seine-Saint-Denis and Val-d'Oise are the only departments to have a positive delta (respectively $+39.13 \%$ and $+7.51 \%$ ), with a very clear demarcation for Seine-Saint-Denis (see Figure 3). Among the cluster, all the other departments have negative delta (see unemployment benefit income in Figure 3). We come to the same observation according to the poverty rate, where four departments have positive deltas with a clear demarcation of the Seine-Saint-Denis $(+84.07 \%)$, then we rank Val-d'Oise $(+8.12 \%)$ and Val-de Marne $(+7.48 \%)$ (see Poverty rate in Figure 3). We find similar result at the observation of social minima where three departments (Seine-Saint-Denis, Vald'Oise and Val-de-Marne) have all positive deltas with a clear demarcation for Seine-Saint-Denis $(+118.20 \%)$, Val-d'Oise and Val-de-Marne tied $(+5.79 \%)$ (see Social minima in income in Figure 3). Finally, concerning the part of individuals without diploma into the workforce, Seine-Saint-Denis still occupies the first 
place with a delta of $+46.12 \%$ compared to the average of the cohort, followed by Val-d'Oise $(+11.60 \%)$, Seine-et-Marne $(5.84 \%)$ and Val-de-Marne $(+4.69 \%)$ (see graph little or no graduate in the work force in Figure 3). Based on the analysis of economic and financial variables, the first conclusion that can be drawn is that there are therefore several common points between Seine-Saint-Denis and Val-d'Oise, two departments having a smaller population of $75+$ but suffering a significant excess mortality, despite social distancing measures implemented by the French Government. Indeed, since the promulgation of the Law 2020-290 of March 23, 2020 said 'Emergency to face the epidemic of COVID-19', prolonged by the Law 2020-546 of May 11, 2020 , the French Government is authorized to rule into legislative matters by decree when it comes to fight against the epidemic in France. In addition, regarding inequalities related to the structure of housing, specifically the unworthily housing, the two departments with positive deltas are Seine-Saint-Denis $(+104.77 \%)$ and Paris $(+77.47 \%)$ (see Potentially unworthly housing in Figure 3). For the average size of households, five departments have a positive delta: Seine-Saint-Denis $(+9.47 \%)$, Seine-et-Marne $(+5.26 \%)$, Yvelines $(+1.05 \%)$, Essonne $(+5.26 \%)$ and Val-d'Oise $(+9.47 \%)$ (see Household size in Figure 3). Finally, four departments have positive deltas at the variable "overcrowded main residences": Seine-Saint-Denis $(+68.16 \%)$, Paris $(+29.79 \%)$, Hauts-de-Seine $(+6.12 \%)$ and Val-de-Marne $(+11.83 \%)$, with a delta far above for Seine-Saint-Denis (see Overcrowded housing in Figure 3).

\section{Conclusion and opening to future work}

Seine-Saint-Denis differs from other departments according to a number of important variables. These variables, on the main field of financial economic poverty, on the one hand, and structural factors linked to housing, on the other hand, may explain the excess mortality during social distancing and lockdown put in place by French Government. Six of these seven variables are also significant in Val-d'Oise, another department which, like Seine-Saint-Denis, has a significant excess mortality with a lower proportion of people over the age of 75 . Our study therefore provides political leaders with a number of inputs allowing them to better implement effective measures in the event of a second wave of COVID-19 or new pandemics due to viruses inside the coronavirus family. Agglomerations with higher precariousness indicators (unemployment benefit income, poverty rate, social minima in income, little or no graduate in the workforce) and less suitable housing (unworthy housing, household size, overcrowded housing) are more at risk, including when their population is younger. It is therefore a requirement to set up new health policies facilitating an accurate monitoring of the inhabitants and their environment in these departments or agglomerations, with the main objective of breaking human-to-human transmission chains more quickly and efficiently. It would be interesting in an additional work to see if, in other countries and other continents, the results obtained at

\footnotetext{
${ }^{5}$ Refer to https://www.legifrance.gouv.fr/.
} 
the occasion of the analysis of structural factors go in the same direction as in Seine-Saint-Denis in France.

\section{References}

Abrams E. M. and Szefler S. J. (2020), "Managing Asthma during COVID-19: An Example for Other Chronic Conditions in Children and Adolescents", The Journal of Pediatrics. Available at: https://doi.org/10.1016/j.jpeds.2020.04.049.

Altmann D. M., Douek D. C. and Boyton R. J. (2020), "What policy makers need to know about COVID-19 protective immunity", The Lancet. Available at: https://doi.org/10.1016/S0140-6736(20)30985-5.

Bacon S., Bates C., et al. (2020), "OpenSAFELY: factors associated with COVID-19-related hospital death in the linked electronic health records of 17 million adult NHS patients", Working Paper, University of Oxford. Available at: https://doi.org/10.1101/2020.05.06.20092999.

Butler D. (2013), "Progress stalled on coronavirus: lack of in-depth studies hampers efforts to identify source", Nature 7467 (501): 294-295. Available at: https://doi.org/10.1038/501294a.

Cohen J. (2020), "Vaccine designers take first shots at COVID-19", Science 368 (6486): 14-6. Available at: https://doi.org/10.1126/science.368.6486.14.

Desjardins M. R., Hohl A. and Delmelle E. M. (2020), "Rapid surveillance of COVID-19 in the United States using a prospective space-time scan statistic: Detecting and evaluating emerging clusters", Applied Geography 118: 102202. Available at: https://doi.org/10.1016/j.apgeog.2020.102202.

Di Lorenzo G. and Di Trolio R. (2020), "Coronavirus Disease (COVID-19) in Italy: Analysis of Risk Factors and Proposed Remedial Measures", Frontiers in medicine 7:140. Available at: https://doi.org/10.3389/fmed.2020.00140.

Gilbert M., Pullano G., et al. (2020), "Preparedness and vulnerability of African countries against importations of COVID-19: a modelling study", The Lancet 395(10227): 871-877. Available at: https://doi.org/10.1016/S01406736(20)30411-6.

Hopman J., Allegranzi B. and Mehtar S. (2020), "Managing COVID-19 in Low- and Middle-Income Countries", JAMA 323(16): 1549-1550. Available at: https://doi.org/10.1001/jama.2020.4169.

Klonoff D. C. and Umpierrez G. E. (2020), "COVID-19 in patients with diabetes: risk factors that increase morbidity", Metabolism: clinical and experimental. Available at: https://doi.org/10.1016/j.metabol.2020.154224.

Li X., Xu S., et al. (2020), "Risk factors for severity and mortality in adult COVID-19 inpatients in Wuhan", The Journal of Allergy and Clinical Immunology. Available at: https://doi.org/10.1016/j.jaci.2020.04.006. 
Liu J., Zhou J., et al. (2020), "Impact of meteorological factors on the COVID19 transmission: A multi-city study in China", Science of the Total Environment 726: 138513.

Martinez-Alvarez M., Jarde A., et al. (2020), "COVID-19 pandemic in west Africa", The Lancet Global Health 8(5): 631-632.

McKee M. and Stuckler D. (2020), "If the world fails to protect the economy, COVID-19 will damage health not just now but also in the future", Nature medicine 26: 640-642. Available at: https://doi.org/10.1038/s41591-020-0863y.

Mihm S. (2020), "COVID-19: Possible Impact of the Genetic Background in IFNL Genes on Disease Outcomes", Journal of Innate Immunity. Available at: https://doi.org/10.1159/000508076.

NHS England (2020), "COVID-19 Daily Deaths". Available at:

https://www.england.nhs.uk/statistics/statistical-work-areas/covid-19-daily-deaths/.

Nuwagira E. and Muzoora C. (2020), "Is Sub-Saharan Africa prepared for COVID-19?", Tropical Medicine and Health 48(18).

Available at: https://doi.org/10.1186/s41182-020-00206-x.

Santé Publique France (2020), "COVID-19 : point épidémiologique du 24 mars 2020". Available at:

https://www.santepubliquefrance.fr/maladies-et-traumatismes/maladies-et-infectionsrespiratoires/infection-a-coronavirus/documents/bulletin-national/covid-19-pointepidemiologique-du-24-mars-2020.

Sargin G. and Yavasoglu S. (2020), "Is Coronavirus Disease 2019 (COVID19) seen less in countries more exposed to Malaria?", Medical Hypotheses 140. Available at: https://doi.org/10.1016/j.mehy.2020.109756.

Shoenfeld Y. (2020), "Corona (COVID-19) time musings: Our involvement in COVID-19 pathogenesis, diagnosis, treatment and vaccine planning", Autoimmunity Reviews 19: 102561. Available at: https://doi.org/10.1016/j.autrev.2020.102538.

Thanh Le T., Andreadakis Z., et al. (2020), "The COVID-19 vaccine development landscape", Nature reviews Drug discovery 19(5): 305-6. Available at: https://doi.org/10.1038/d41573-020-00073-5.

Webb Hooper M., Nápoles A. M. and Pérez-Stable E. J. (2020), "COVID-19 and Racial/Ethnic Disparities", JAMA.

Available at: https://doi.org/10.1001/jama.2020.8598.

WHO (2020a), "WHO Director-General's opening remarks at the media briefing on COVID-19 - 11 March 2020". Available at:

https://www.who.int/dg/speeches/detail/who-director-general-s-opening-remarksat-the-media-briefing-on-covid-19-11-march-2020.

WHO (2020b), "Clinical management of severe acute respiratory infection when COVID-19 is suspected". Available at: 
https://www.who.int/publications-detail/clinical-management-of-severe-acute-respiratoryinfection-when-novel-coronavirus-(ncov)-infection-is-suspected.

Yue X. G., Shao X. F., et al. (2020), "Risk Prediction and Assessment: Duration, Infections, and Death Toll of the COVID-19 and Its Impact on China's Economy", Journal of Risk and Financial Management 13(4) 66. Available at: https://doi.org/10.3390/jrfm13040066. 
Table 3: Values of the delta percentage of our panel of data for each departments - Part I

\begin{tabular}{|c|c|c|c|c|c|c|}
\hline Departments & 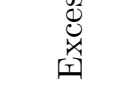 & $\stackrel{0}{\circ}$ & $\stackrel{\circ}{\stackrel{8}{\circ}}$ & $\stackrel{\circ}{\stackrel{9}{+}}$ & $\stackrel{8}{\stackrel{8}{8}}$ & $\frac{\pi}{2}$ \\
\hline Paris & $73,90 \%$ & $-37,41 \%$ & $18,28 \%$ & $-4,97 \%$ & $7,17 \%$ & $14,38 \%$ \\
\hline Seine-et-Marne & $71,70 \%$ & $5,55 \%$ & $-8,82 \%$ & $2,29 \%$ & $3,93 \%$ & $-7,41 \%$ \\
\hline Yvelines & $66,60 \%$ & $2,34 \%$ & $-15,93 \%$ & $3,63 \%$ & $6,78 \%$ & $14,38 \%$ \\
\hline Essonne & $88,20 \%$ & $4,76 \%$ & $-6,47 \%$ & $0,98 \%$ & $-0,54 \%$ & $2,45 \%$ \\
\hline Hauts-de-Seine & $127,80 \%$ & $-6,54 \%$ & $3,56 \%$ & $1,31 \%$ & $-3,09 \%$ & $8,48 \%$ \\
\hline Seine-Saint-Denis & $128,10 \%$ & $10,44 \%$ & $4,51 \%$ & $-2,28 \%$ & $-15,50 \%$ & $-38,51 \%$ \\
\hline Val-de-Marne & $96,50 \%$ & $-1,70 \%$ & $1,44 \%$ & $-0,13 \%$ & $-0,93 \%$ & $2,71 \%$ \\
\hline Val-d'Oise & $88,60 \%$ & $9,18 \%$ & $-4,52 \%$ & $-1,36 \%$ & $-1,22 \%$ & $-15,54 \%$ \\
\hline
\end{tabular}

\section{Appendix}


Table 4: Values of the delta percentage of our panel of data for each departments - Part II

\begin{tabular}{|c|c|c|c|c|c|c|}
\hline & 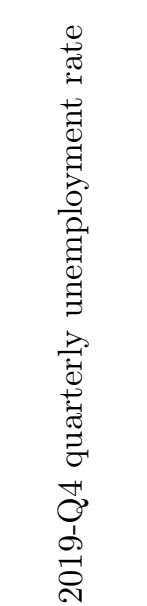 & 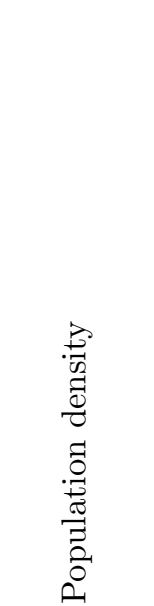 & 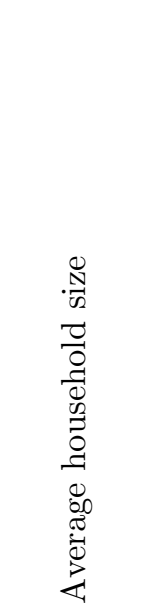 & 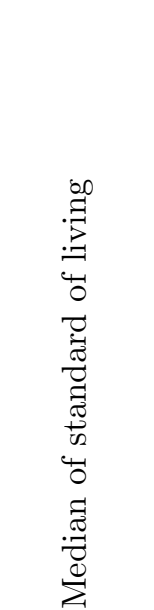 & 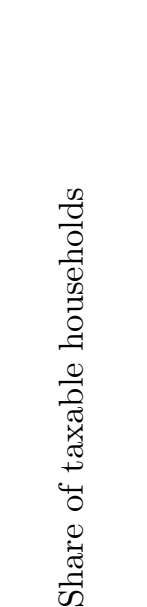 & 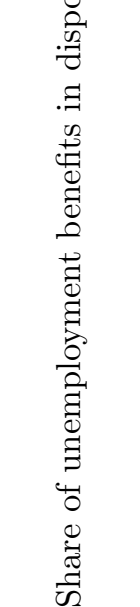 \\
\hline Paris & $-14,04 \%$ & $270,31 \%$ & $-20,00 \%$ & $15,85 \%$ & $8,98 \%$ & $-5,14 \%$ \\
\hline Seine-et-Marne & $-7,11 \%$ & $-95,79 \%$ & $5,26 \%$ & $-2,43 \%$ & $-1,78 \%$ & $-5,14 \%$ \\
\hline Yvelines & $-14,04 \%$ & $-88,83 \%$ & $1,05 \%$ & $11,60 \%$ & $10,40 \%$ & $-14,62 \%$ \\
\hline Essonne & $-9,88 \%$ & $-87,29 \%$ & $5,26 \%$ & $-0,06 \%$ & $2,81 \%$ & $-8,30 \%$ \\
\hline Hauts-de-Seine & $-12,65 \%$ & $62,69 \%$ & $-7,37 \%$ & $14,83 \%$ & $10,72 \%$ & $-11,46 \%$ \\
\hline Seine-Saint-Denis & $44,19 \%$ & $21,21 \%$ & $9,47 \%$ & $-26,55 \%$ & $-24,40 \%$ & $39,13 \%$ \\
\hline Val-de-Marne & $-0,17 \%$ & $0,22 \%$ & $-3,16 \%$ & $-5,11 \%$ & $-1,46 \%$ & $-1,98 \%$ \\
\hline Val-d'Oise & $13,69 \%$ & $-82,52 \%$ & $9,47 \%$ & $-8,13 \%$ & $-5,26 \%$ & $7,51 \%$ \\
\hline
\end{tabular}


Table 5: Values of the delta percentage of our panel of data for each departments - Part III

\begin{tabular}{lcccccc} 
& ๘ & \multicolumn{1}{c}{} & ๘ & ๘ & ๘ & ๘ \\
Paris & $-27,27 \%$ & $1,69 \%$ & $-30,97 \%$ & $52,54 \%$ & $44,56 \%$ & $-97,14 \%$ \\
Seine-et-Marne & $-7,44 \%$ & $-25,34 \%$ & $5,85 \%$ & $-25,87 \%$ & $-39,52 \%$ & $84,59 \%$ \\
Yvelines & $-47,11 \%$ & $-37,57 \%$ & $-15,24 \%$ & $10,18 \%$ & $-16,22 \%$ & $35,35 \%$ \\
Essonne & $-14,05 \%$ & $-16,98 \%$ & $-0,29 \%$ & $-10,75 \%$ & $-22,49 \%$ & $49,01 \%$ \\
Hauts-de-Seine & $-33,88 \%$ & $-21,48 \%$ & $-21,76 \%$ & $31,61 \%$ & $29,62 \%$ & $-63,15 \%$ \\
Seine-Saint-Denis & $118,18 \%$ & $84,07 \%$ & $46,12 \%$ & $-33,69 \%$ & $10,51 \%$ & $-22,48 \%$ \\
Val-de-Marne & $5,79 \%$ & $7,48 \%$ & $4,70 \%$ & $-2,43 \%$ & $13,50 \%$ & $-29,47 \%$ \\
Val-d'Oise & $5,79 \%$ & $8,13 \%$ & $11,60 \%$ & $-21,59 \%$ & $-19,96 \%$ & $43,29 \%$
\end{tabular}


Table 6: Values of the delta percentage of our panel of data for each departments - Part IV

\begin{tabular}{|c|c|c|c|c|c|c|}
\hline & 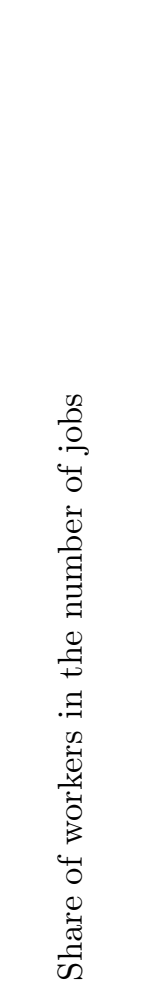 & 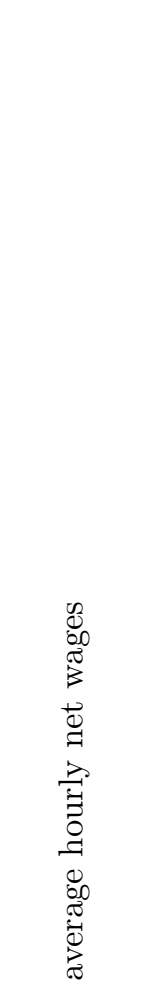 & 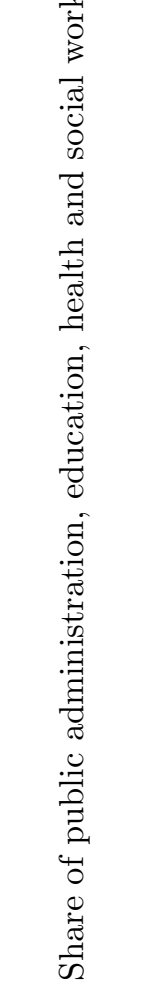 & 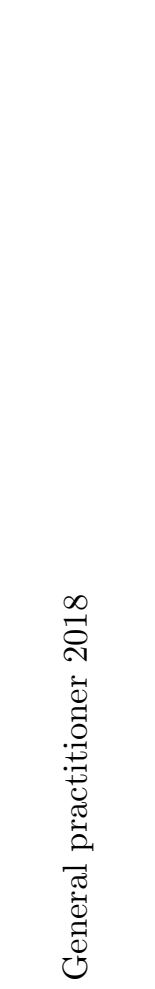 & 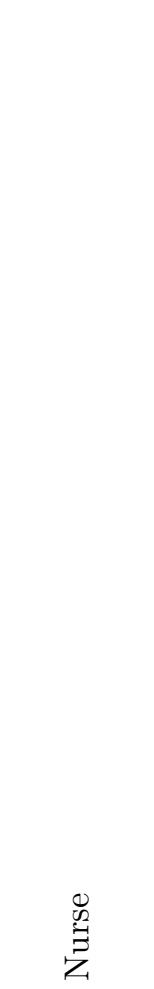 & 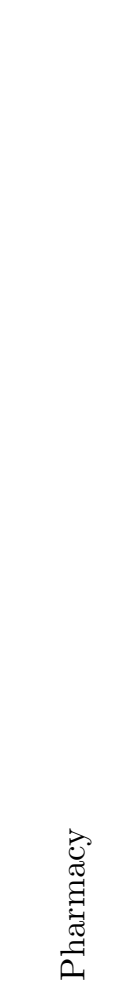 \\
\hline Paris & $-37,74 \%$ & $28,90 \%$ & $-9,94 \%$ & $116,64 \%$ & $126,70 \%$ & $114,95 \%$ \\
\hline Seine-et-Marne & $39,25 \%$ & $-14,55 \%$ & $6,47 \%$ & $-15,67 \%$ & $-1,90 \%$ & $-23,91 \%$ \\
\hline Yvelines & $-4,27 \%$ & $14,69 \%$ & $-0,09 \%$ & $-9,61 \%$ & $-24,89 \%$ & $-15,39 \%$ \\
\hline Essonne & $11,80 \%$ & $-8,35 \%$ & $8,30 \%$ & $-26,61 \%$ & $-12,76 \%$ & $-27,05 \%$ \\
\hline Hauts-de-Seine & $-47,11 \%$ & $24,93 \%$ & $-38,38 \%$ & $1,67 \%$ & $-24,71 \%$ & $4,98 \%$ \\
\hline Seine-Saint-Denis & $12,47 \%$ & $-25,12 \%$ & $4,65 \%$ & $-16,09 \%$ & $-17,10 \%$ & $-14,28 \%$ \\
\hline Val-de-Marne & $1,76 \%$ & $-6,78 \%$ & $12,31 \%$ & $-21,39 \%$ & $-28,24 \%$ & $-12,43 \%$ \\
\hline Val-d'Oise & $23,85 \%$ & $-13,71 \%$ & $16,68 \%$ & $-28,96 \%$ & $-17,10 \%$ & $-26,87 \%$ \\
\hline
\end{tabular}


Table 7: Values of the delta percentage of our panel of data for each departments - Part V

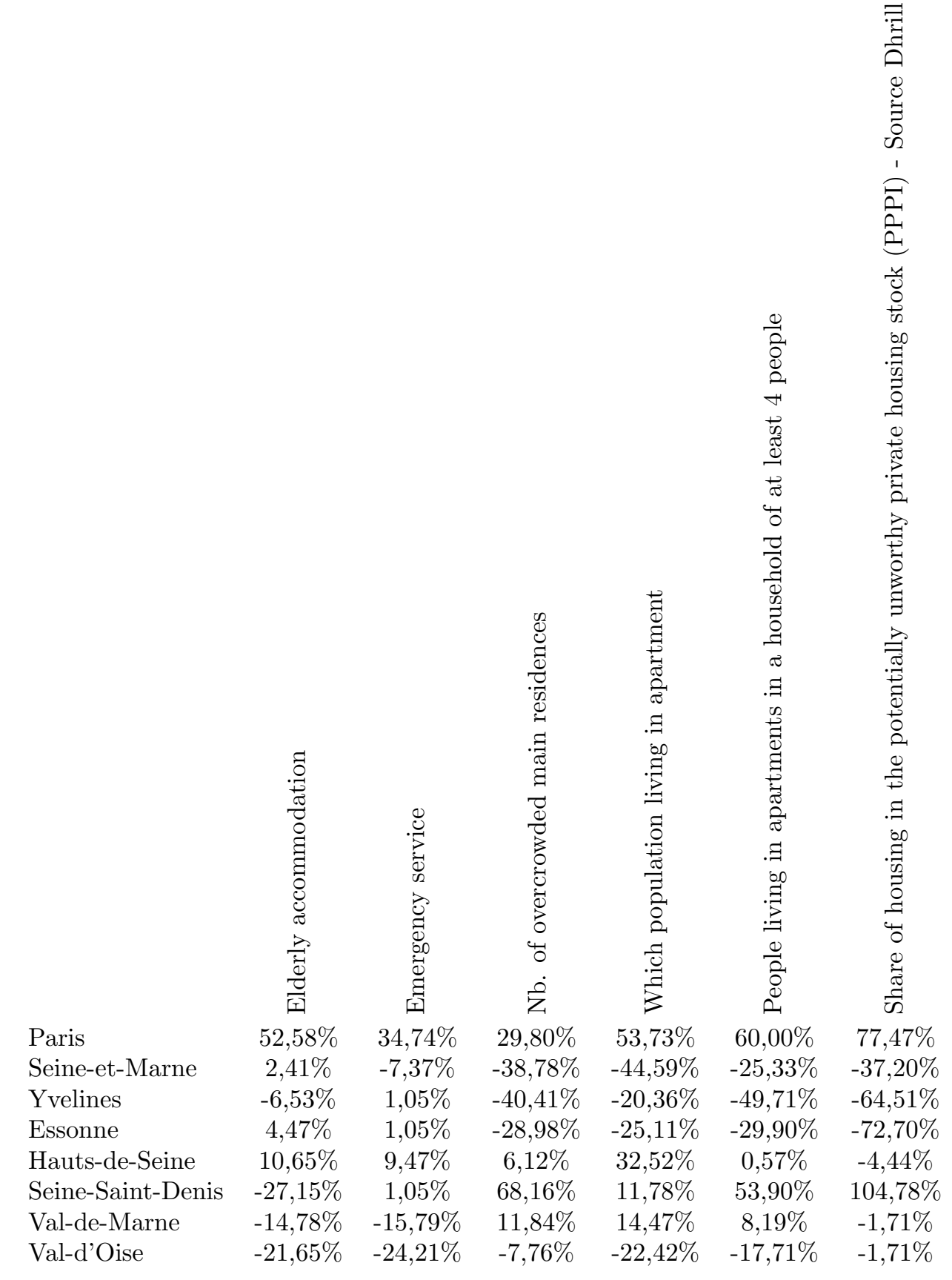

